\title{
Pengaruh Online Marketing Strategy Terhadap Keputusan Pembelian (Studi Kasus Pada Mahasiswa STIE Mulia Darma Pratama Palembang)
}

\author{
Sopian \\ Sekolah Tinggi IImu Ekonomi Mulia Darma Pratama, akangsopi@gmail.com
}

\begin{abstract}
ABSTRAK
Permasalah yang dibahas dalam penelitian ini adalahadakah pengaruh online marketing strategyditinjau dari aspek product, price, place dan promotionterhadap keputusan pembelian? Populasi dalam penelitian ini adalah seluruh mahasiswa STIE Mulia Darma Pratama yang pernah belanja online. Teknik sampel yang digunakan dalam penelitianSampling Aksidental. Adapun sampel pada penelitian ini sebanyak 50 orang STIE Mulia Darma Pratama yang pernah belanja online.Hasil penelitian menunjukkan bahwa pengujian secara simultan $(U j i \mathrm{~F})$, diperoleh $F_{\text {hitung }}(22,133)>F_{\text {tabel }}$ $(2,422)$ jadi Ha diterima dan Ho ditolakdapat disimpulkan bahwa variabel product $\left(\mathrm{X}_{1}\right)$, price $\left(\mathrm{X}_{2}\right)$, place $\left(\mathrm{X}_{3}\right)$, dan promotion $\left(\mathrm{X}_{4}\right)$ secara bersama-sama berpengaruh terhadap keputusan pembelian $(\mathrm{Y})$. Hasil pengujian secara parsial $(\mathrm{Uji} \mathrm{t})$ dapat dijelaskan: variabel product $\left(\mathrm{X}_{1}\right)$ berpengaruh signifikan terhadap keputusan pembelian $(Y)$ diperoleh thitung sebesar 3,165 dengan nilai signifikan sebesar 0,002 , jadi nilai thitung $(3,165)>$ tabel $(1,679)$ Ha diterima dan Ho ditolak. Variabel price $\left(\mathrm{X}_{2}\right)$ berpengaruh signifikan terhadap keputusan pembelian $(Y)$ hasil diperoleh thitung sebesar 6,682 dengan nilai signifikan sebesar 0,000 , jadi nilai thitung $(6,682)>$ tabel $(1,679)$ Haditerima dan Ho ditolak. Variabel Place $\left(\mathrm{X}_{3}\right)$ tidak berpengaruh signifikan terhadap keputusan pembelian $(\mathrm{Y})$ hasil diperoleh thitung sebesar 0,153 dengan nilai signifikan sebesar 0,879 , jadi nilai thitung $(0,153)<$ tabel $(1,679)$ Ha ditolak dan Ho diterima.Variabel promotion $\left(\mathrm{X}_{4}\right)$ berpengaruh tapi tidak signifikan terhadap keputusan pembelian $(Y)$ hasil diperoleh thitung sebesar 2,209 dengan nilai signifikan sebesar 0,031 , jadi nilai thitung $(2,209)>$ tabel $(1,679)$ Ha diterima dan Ho ditolak.
\end{abstract}

Kata Kunci:product, price, place, promotion, dan keputusan pembelian

\begin{abstract}
The problem discussed in this study is is there an influence of online marketing strategy in terms of product, price, place and promotion aspects of purchasing decisions? The population in this study were all STIE Mulia Darma Pratama students who had shopped online. Sample technique used in accidental sampling research. The samples in this study were 50 people from STIE Mulia Darma Pratama who had shopped online. The results showed that simultaneous testing (Test F), obtained Fcount $(22,133)>$ Ftable $(2,422)$ so Ha was accepted and Ho was rejected it could be concluded that the product variables (X1), price (X2), place (X3), and promotion (X4) jointly influences the purchase decision ( $Y$ ). Partial test results ( $t$ test) can be explained: product variable $(X 1)$ has a significant effect on purchasing decisions (Y) obtained tcount of 3.165 with a significant value of 0.002 , so tcount (3.165)> ttable (1.679) Ha is accepted and Ho is rejected. Price variable (X2) significantly influences the purchase decision $(Y)$, the result is tcount of 6.682 with a significant value of 0.000 , so tcount (6.682) > ttable (1.679) Ha is accepted and Ho is rejected. Place variable (X3) does not have a significant effect on purchasing decisions $(Y)$, the result is tcount of 0.153 with a significant value of 0.879 , so the value of tcount $(0.153)<t t a b l e(1.679) \mathrm{Ha}$ is rejected and Ho is accepted. The promotion variable (X4) influences but is not significant to the purchasing decision (Y). The result is obtained tcount of 2.209 with a significant value of 0.031 , so the value of tcount (2.209)> ttable (1.679) Ha is accepted and Ho is rejected.
\end{abstract}

Keywords: product, price, place, promotion, and purchasing decisions

\section{A. PENDAHULUAN}

Keberhasilan pemasaran suatu produk tidak hanya dinilai dari seberapa banyak konsumen yang berhasil diperoleh namun juga bagaimana cara mempertahankan konsumen tersebut. Dalam pemasaran dikenal bahwa setelah konsumen 
melakukan keputusan pembelian, ada proses yang dinamakan puas dan tidak puas konsumen terletak pada hubungan antara harapan dengan prestasi yang diterima dari produk atau jasa. Bila produk atau jasa tidak memenuhi harapan konsumen tidak akan melakukan pembelian ulang. Dilain pihak apabila sebuah produk atau jasa melebihi harapan konsumen, maka konsumen akan merasa puas dan memungkinkan untuk melakukan pembelian ulang. Perkembangan teknologi yang semakin pesat mulai digunakan tidak hanya untuk melakukan tukar informasi, berita, dan semacamnya, namun saat ini teknologi sudah mulai digunakan untuk merambah dan memajukan dunia bisnis.

Menurut Lesser Robert Bittle yang dikutip oleh Alma (2013:199) "Strategi adalah suatu rencana yang fundamental untuk mencapai tujuan perusahaan". Menurut Kotler yang dikutip oleh Sunyoto (2014:18), Pemasaran adalah proses sosial dan manajerial dimana seseorang atau kelompok memperoleh apa yang mereka butuhkan dan inginkan melalui penciptaan atau pertukaran produk dan nilai.

Menurut Kotler (2004:81), "Strategi pemasaran adalah pola pikir pemasaran yang akan digunakan untuk mencapai tujuan pemasarannya. Strategi pemasaran berisi strategi spesifik untuk pasar sasaran, penetapan posisi, bauran pemasaran dan besarnya pengeluaran pemasaran.Setelah strategi pemasaran ditetapkan maka perusahaan diharapkan untuk menerapkan dan merencanakan rincian bauran pemasaran".

Menurut Kotler (2002:17-18), Bauran pemasaran terdiri dari semua hal yang dapat dilakukan perusahaan untuk mempengaruhi permintaan akan produknya yang terdiri dari "4P" yaitu:

1. Product, kombinasi barang dan jasa yang ditawarkan perusahaan kepada pasar sasaran meliputi : ragam, kualitas, desain. fitur, nama merek, dan kemasan.

2. Price, adalah sejumlah uang yang harus dibayarkan pelanggan untuk memperoleh produk meliputi: daftar harga, diskon potongan harga, periode pembayaran, dan persyaratan kredit.

3. Place, kegiatan perusahaan yang membuat produk tersedia bagi pelanggan sasaran meliputi: Lokasi, saluran distribusi, persediaan, transportasi dan logistik.

4. Promotion, berarti aktivitas yang menyampaikan manfaat produk dan membujuk pelanggan membelinya meliputi : Iklan dan promosi penjualan.

Berkembangnya internet banyak
hal baru yang timbul dari berkembangnya internet tersebut salah satunya adalah pembelian atau belanja barang ataupun jasa secara online. Internet saat ini dirasa bisa menjadi solusi pemasaran yang sangat bagus karena bisa diakses oleh orang dalam waktu yang tanpa batas dan bisa diakses oleh orang lain darimana saja berada. Pemasaran media online dapat dikatakan sebagai bisnis yang menjanjikan untuk saat ini. Selain itu internet dapat membantu kinerja perusahaan menjadi lebih efektif dan efesien, sehingga dengan meningkatnya kinerja sebuah toko atau perusahaan diharapkan dapat menambah dan mengurangi kesalahan yang disebabkan oleh faktor manusia.

Online marketing merupakan segala usaha yang dilakukan untuk melakukan pemasaran suatu produk atau jasa melalui atau menggunakan media internet. Internet merupakan 
salah satu penemuan mutakhir era globalisasi dibidang teknologi informasi yang sangat menguntungkan semua manusia diseluruh dunia untuk berbagi informasi dan berkomunikasi, termasuk berbagi informasi produk atau jasa yang dijual.

Dengan perkembangan teknologi informasi saat ini, telah menciptakan jenis-jenis dan peluang-peluang bisnis yang baru di mana transaksi-transaksi bisnis makin banyak dilakukan secara elektronika. Sehubungan dengan perkembangan teknologi informasi tersebut memungkinkan setiap orang dengan mudah melakukan perbuatan hukum seperti misalnya melakukan jual-beli. Perkembangan internet memang cepat dan memberi pengaruh signifikan dalam segala aspek kehidupan kita. Internet membantu kita sehingga dapat berinteraksi, berkomunikasi, bahkan melakukan perdagangan dengan orang dari segala penjuru dunia dengan murah, cepat dan mudah. beberapa tahun terakhir ini dengan begitu merebaknya media internet menyebabkan banyaknya perusahaan yang mulai mencoba menawarkan berbagai macam produknya dengan menggunakan media ini. Dan salah satu manfaat dari keberadaan internet adalah sebagai media promosi suatu produk. Suatu produk yang dionlinekan melalui internet dapat membawa keuntungan besar bagi pengusaha karena produknya di kenal di seluruh dunia.

Penggunaan internet tidak hanya terbatas pada pemanfaatan informasi yang dapat diakses melalui media ini, melainkan juga dapat digunakan sebagai sarana untuk melakukan transaksi perdagangan yang sekarang di Indonesia telah mulai diperkenalkan melalui beberapa seminar dan telah mulai penggunaannya oleh beberapa perusahaan yaitu electroniccommerce atau yang lebih dikenal dengan $E$ Commerce, yang merupakan bentuk perdagangan secara elektronik melalui media internet. E-Commerce pada dasarnya merupakan suatu kontak transaksi perdagangan antara penjual dan pembeli dengan menggunakan media internet. Jadi proses pemesanan barang dikomunikasikan melalui internet. Menurut Suyanto (2007:7) E-Commerce adalah suatu kumpulan yang dinamis antara teknologi, aplikasi dan proses bisnis yang menghubungkan perusahaan, konsumen dan komunitas tertentu melalui transaksi elektronik.

\section{Keberadaan}

E-Commerce merupakan alternatif bisnis yang cukup menjanjikan untuk diterapkan pada saat ini, karena E-Commerce memberikan banyak kemudahan bagi kedua belah pihak, baik dari pihak penjual (merchant) maupun dari pihak pembeli (buyer) di dalam melakukan transaksi perdagangan, meskipun para pihak berada di dua benua berbeda sekalipun. Dengan E-Commerce setiap transaksi tidak memerlukan pertemuan dalam tahap negoisasi. Oleh karena itu jaringan internet ini dapat menembus batas geografis dan teritorial termasuk yurisdiksi hukumnya.

Toko online merupakan tempat jual beli online di dunia maya. Bisnis ini bisa menggunakan modal maupun tanpa modal. Bagi yang memiliki modal, mereka bisa menyediakan barang-barang yang akan mereka jual terlebih dahulu, kemudian mereka pasarkan melalui jaringan internet kepada masyarakat luas. Cara memasarkan bisa melalui media sosial sepertitwitter,

facebook, istagram, Googleplus maupun melalui website pribadi atau bisa juga melalui website khusus yang dipersiapkan oleh pihak ketiga seperti: olx.com, tokopedia.com, bukalapak.com, 
elevenia.com, blibli.com, traveloka, shopee, blanja.com, tiket.com dan website-website sejenis lainnya. Sedangkan bagi yang tidak memiliki modal, mereka bisa mempergunakan fasilistas-fasilitas yang mereka memiliki seperti jaringan pertemanan (media sosial) atau website pribadi yang dimilikinya untuk ikut serta memasarkan produk atau barang barang orang lain.

Setiap perusahaan harus memperhatikan dan merancang strategi yang tepat guna merebut hati pelanggan agar membeli kembali dan kesediaan mereka untuk menjadi partner perusahaantersebut terhadap produk yang ditawarkan. Menurut Kotler (2008:201)keputusan pembelian konsumen terhadap sebuah produk sangat penting karena dengan melakukan pembelian, maka evaluasi paska pembelian terjadi.Kotler dan Keller (2009:208) menyatakan keputusan pembelian yang dilakukanoleh para konsumen melalui 5 (lima) tahap yaitu, (1) pengenalan masalah, (2) pencarian informasi. (3) evaluasi alternatif, (4) keputusan membeli atau tidak, (5) perilaku pascapembelian.Namun para konsumen tidak selalu melewati seluruh lima tahapan ketika membeli produk, mereka bisa melewati atau membalik tahap.Sedangkanmenurut Tjiptono (2008:25) keputusan pembelian konsumen adalah pemilihan satu tindakan dari dua atau lebih pilihan alternatif.

Belanja online dikalangan mahasiswa STIE Mulia Darma Pratamadapat dilakukan dengan cara melakukan window shopping online pada webyang dituju. Kemudian, pembeli dapat mengeklik barang yang diinginkan. Setelah itu pembeli kemudian dibawa kepada jendela yang menampilkan tata cara pembayaran yang disepakati dan kemudian setelahnominal uang ditransfer, maka penjual akan mengirim barang melalui jasa pos dan sebagainya. Pembayaran dapat dilakukan baik menggunakan kartu debit, kartu kredit, PayPal, memotong pulsa pelanggan (untuk transaksi lewat $H P$ ), cek maupun $C O D$ (Cash On Delivery) yaitu pembayaran yang dilakukan ketika barang telahdikirim oleh penjual. Cash On Delivery biasanya dilakukan melalui tatap mukaantara penjual dan pembeli, penjual dapat menunjukkan barangnya sehinggapembeli yang tertarik bisa meneliti barang yang akan ia beli.Pembelian semacamini biasanya melakukan pembayaran secara langsung atau uang kontan. Selain tataplangsung antara penjual dan pembeli, $C O D$ ini bisa dilakukan antara kurir danpembeli biasanya penjual hanya akan melayani $C O D$ apabila daerah pembelimasih dapat dijangkau oleh penjual.

\section{B. KAJIAN TEORI \\ 1) Strategi Pemasaran}

Menurut Lesser Robert Bittle yang dikutip oleh Alma (2013:199) "Strategi adalah suatu rencana yang fundamental untuk mencapai tujuan perusahaan". Menurut Kotler yang dikutip oleh Sunyoto (2014:18), Pemasaran adalah proses sosial dan manajerial dimana seseorang atau kelompok memperoleh apa yang mereka butuhkan dan inginkan melalui penciptaan atau pertukaran produk dan nilai.

Menurut Kotler (2004:81), "Strategi pemasaran adalah pola pikir pemasaran yang akan digunakan untuk mencapai tujuan pemasarannya. Strategi pemasaran berisi strategi spesifik untuk pasar sasaran, penetapan posisi, bauran pemasaran dan besarnya pengeluaran pemasaran.Setelah strategi 


\section{pemasaran ditetapkan maka perusahaan diharapkan untuk menerapkan dan merencanakan rincian bauran pemasaran".}

Menurut Kotler (2002:17-18), Bauran pemasaran terdiri dari semua hal yang dapat dilakukan perusahaan untuk mempengaruhi permintaan akan produknya yang terdiri dari "4P" yaitu:

a. Product, kombinasi barang dan jasa yang ditawarkan perusahaan kepada pasar sasaran meliputi : ragam, kualitas, desain. fitur, nama merek, dan kemasan.

b. Price, adalah sejumlah uang yang harus dibayarkan pelanggan untuk memperoleh produk meliputi: daftar harga, diskon potongan harga, periode pembayaran, dan persyaratan kredit.

c. Place, kegiatan perusahaan yang membuat produk tersedia bagi pelanggan sasaran meliputi: Lokasi, saluran distribusi, persediaan, transportasi dan logistik.

d. Promotion, berarti aktivitas yang menyampaikan manfaat produk dan membujuk pelanggan membelinya meliputi : Iklan dan promosi penjualan.

2) Keputusan Pembelian Menurut (2008:201)keputusan
Kotler pembelian konsumen terhadap sebuah produk sangat penting karena dengan melakukan pembelian, maka evaluasi paska pembelian terjadi.Kotler dan Keller (2009:208) menyatakan keputusan pembelian yang dilakukanoleh para konsumen melalui 5 (lima) tahap yaitu :

a. Pengenalan masalah

b. Pencarian informasi

c. Evaluasi alternative

d. Keputusan membeli atau tidak

e. Perilaku pascapembelian

Namun para konsumen tidak selalu melewati seluruh lima tahapan ketika membeli produk, mereka bisa melewati atau membalik beberapa tahap.Sedangkanmenurut Tjiptono (2008:25) keputusan pembelian konsumen adalah pemilihan satu tindakan dari dua atau lebih pilihan alternatif.

\section{$>\quad$ Kerangka Pemikiran}

Kerangka pikir menunjukkan semua variabel yang diteliti, baik pokok maupun variabel lain yang menyertainya. Seluruh variabel yang dilibatkan dalam penelitian tersebut dapat dijelaskan keterkaitannya secara sistematik dalam teori ini untuk diuji.

Untuk lebih jelasnya, hubungan keduanya dapat ditunjukkan pada bagan keterkaitan dibawah ini :

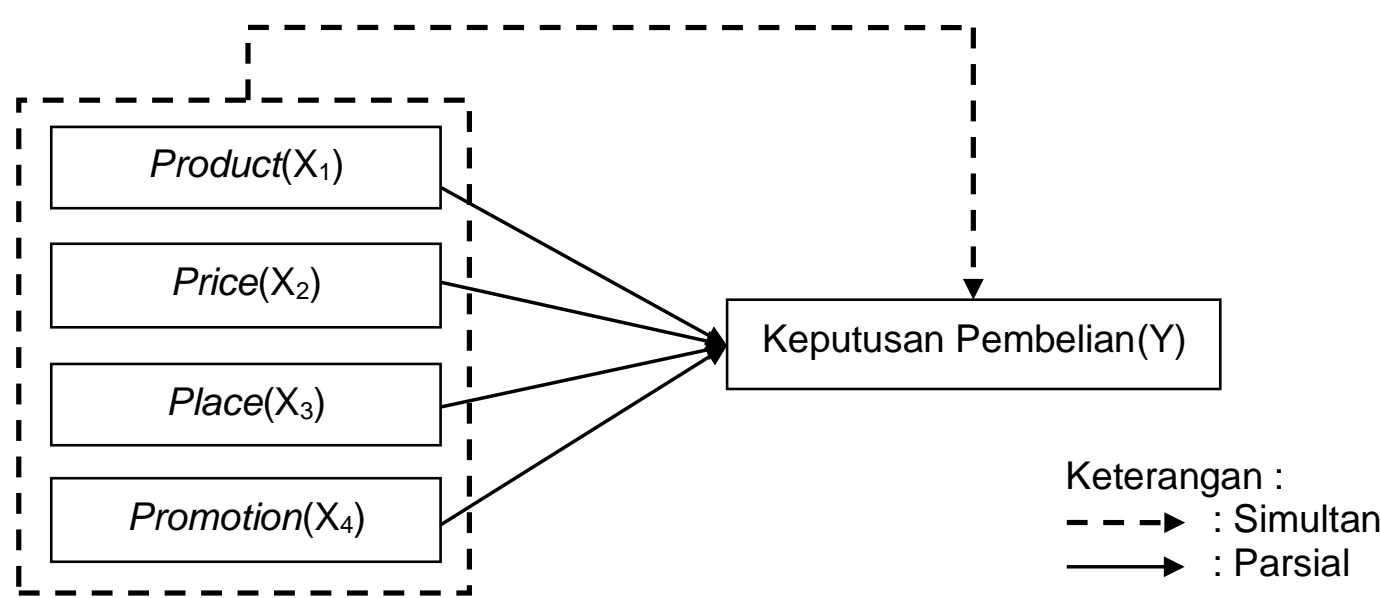

Gambar Kerangka Pemikiran 
$>$ Hipotesis

Menurut Sugiyono (2010:84), hipotesis adalah jawaban atau dugaan sementara terhadap masalah yang diteliti.

Untuk menjawab perumusan masalah pertama, hipotesis yang akan dirumuskan sebagai berikut:

Ho: $\mathbf{b}_{1}, \mathbf{b}_{2}, \mathbf{b}_{3}, \mathbf{b}_{\mathbf{4}}=\mathbf{0}$ :

diduga secara simultan tidak terdapat pengaruh yang positif dan signifikan online marketing strategy ditinjau dari aspek product, price, place dan promotion secara parsial terhadap keputusan pembelian.

$\mathrm{Ha}: \mathbf{b}_{1}, \mathbf{b}_{2}, \mathbf{b}_{3}, \mathbf{b}_{4} \neq \mathbf{0}:$

diduga secara simultan terdapat pengaruh yang positif dan signifikan online marketing strategy ditinjau dari aspek product, price, place dan promotion secara parsial terhadap keputusan pembelian.

Untuk menjawab perumusan masalah pertama, hipotesisyang akan dirumuskan sebagai berikut:

Ho: $\mathbf{b}_{1}, \mathbf{b}_{2}, \mathbf{b}_{3}, \mathbf{b}_{4}=\mathbf{0}$ :

diduga secara parsial tidak terdapat pengaruh yang positif dan signifikan online marketing strategy ditinjau dari aspek product, price, place dan promotion secara parsial terhadap keputusan pembelian.

$\mathrm{Ha}: \mathbf{b}_{1}, \mathbf{b}_{2}, \mathbf{b}_{3}, \mathbf{b}_{4} \neq \mathbf{0}$ :

diduga secara parsial terdapat pengaruh yang positif dan signifikan online marketing strategy ditinjau dari aspek product, price, place dan promotion secara parsial terhadap keputusan pembelian.

\section{METODE PENELITIAN}

Metode penelitian yang digunakan dalam penelitian ini adalah metode asosiatif. Menurut Sugiyono
(2010:11) Penelitian asosiatif merupakan penelitian yang betujuan untuk mengetahui antara dua variabel atau lebih. Metode asosiatif dalam penelitian ini adalah untuk mendeskripsikan hubungan antara strategi pemasaran terhadap keputusan pembelian.

\section{POPULASI DAN SAMPEL \\ 1. Populasi}

Menurut Sugiyono (2010:61) populasi adalah sejumlah anggota yang terdiri atas obyek atau subjek yang mempunyai kualitas dan karakteristik tertentu yang ditetapkan oleh peneliti untuk dipelajari dan kemudian ditarik kesimpulannya. Populasi dalam penelitian ini adalah seluruh mahasiswa STIE Mulia Darma Pratama yang pernah belanja online.

\section{Sampel}

Menurut Sugiyono (2010:62) sampel adalah bagian dari jumlah karakterisik yang dimiliki oleh populasi. Teknik sampel yang digunakan dalam penelitian Sampling Aksidental adalah teknik penentuan sampel berdasarkan kebetulan, yaitu siapa saja yang secara kebetulanbertemu dengan peneliti pada saat penyebaran kuesioner mahasiswa STIE Mulia Darma Pratama yang pernah belanja online, bila dipandang orang yang kebetulan ditemui itu cocok sebagai sumber data (Sugiyono, 2010: 67). Adapun sampel pada penelitian ini sebanyak 50 orang STIE Mulia Darma Pratama yang pernah belanja online.

\section{E. TEKNIK ANALISIS DATA}

Teknik analisis data yang digunakan dalam penelitian ini adalah metode analisis kualitatif dan metode analisis kuantitatif yang artinya analisis yang berlandaskan pada filsafat positivisme, digunakan untuk meneliti pada populasi dan sampel tertentu, 
pengumpulan data menggunakan instrumen penelitian, analisis data bersifat kuantitatif/statistik, dengan tujuan untuk menguji hipotesis yang telah ditetapkan (Sugiyono, 2010:13). Sebelum melakukan pengujian hipotesis dilakukan uji validitas, uji reliabilitas, regresi linier berganda, uji $F$, uji t dan koefisien determinasi $\left(R^{2}\right)$.

Membuat model hubungan anara variabel $\operatorname{product}\left(\mathrm{X}_{1}\right)$, $\operatorname{price}\left(\mathrm{X}_{2}\right)$, place $\left(\mathrm{X}_{3}\right)$ dan promotion $\left(\mathrm{X}_{4}\right)$ dapat diketahui faktor terpenting atau dominan yang menentukan pengaruhnya terhadap keputusan pembelian ( $Y$ ) dengan regresi linier berganda.

\begin{tabular}{ll}
\hline $\mathrm{Y}=\mathrm{a}+\mathrm{b}_{1} \mathrm{X}_{1}+\mathrm{b}_{2} \mathrm{X}_{2}+\mathrm{b}_{3} \mathrm{X}_{3}+\mathrm{b}_{4} \mathrm{X}_{4}$ \\
Keterangan: \\
$\mathrm{Y}$ & $:$ Keputusan pembelian \\
$\mathrm{X}_{1}$ & $:$ Product \\
$\mathrm{X}_{2}$ & $:$ Price \\
$\mathrm{X}_{3}$ & $:$ Place \\
$\mathrm{X}_{4}$ & $:$ Promotion \\
$\mathrm{b}_{1}, \mathrm{~b}_{2}, \mathrm{~b}_{3}, \mathrm{~b}_{4}$ & $:$ Koefisien Regresi \\
$\mathrm{a}$ & $:$ Nilai konstanta
\end{tabular}

Langkah-langkah untuk menjawab perumusan masalah adalah sebagai berikut :

\section{Untuk menjawab perumusan masalah pertama langkah- langkah yang harus dilakukan adalah sebagai berikut :}

a. Merumuskan hipotesis yang dapat dirumuskan sebagai berikut:

Ho: $\mathbf{b}_{1}, \mathbf{b}_{2}, \mathbf{b}_{3}, \mathbf{b}_{4}=\mathbf{0}$ :

diduga tidak terdapat pengaruh yang positif dan signifikan online marketing strategy yang ditinjau dari variabel product $\left(\mathrm{X}_{1}\right)$, price $\left(\mathrm{X}_{2}\right)$, place $\left(\mathrm{X}_{3}\right)$ dan promotion $\left(\mathrm{X}_{4}\right)$ secara simultan terhadap keputusan pembelian (Y).

$\mathrm{Ha}: \mathbf{b}_{1}, \mathbf{b}_{2}, \mathbf{b}_{3}, \mathbf{b}_{4} \neq \mathbf{0}$ :

diduga secara simultan terdapat pengaruh yang positif dan signifikan online marketing strategy yang ditinjau dari variabel product $\left(\mathrm{X}_{1}\right)$, price $\left(\mathrm{X}_{2}\right)$, place $\left(\mathrm{X}_{3}\right)$ dan promotion $\left(\mathrm{X}_{4}\right)$ secara simultan terhadap keputusan pembelian $(Y)$.

b. Melakukan Uji F (secara simultan)

Uji $F$ pada dasarnya menunjukkan apakah semua variabel bebas yang dimasukkan dalam model mempunyai pengaruh secara bersama-sama terhadap variabel terikat.

Menurut Priyatno, (2010:67) $F_{\text {hitung }}$ dapat dicari dengan rumus sebagai berikut:

$$
F_{\text {hitung }}=\frac{R^{2} / k}{\left(1-R^{2}\right)(n-k-1)}
$$

dimana :

$\mathrm{R}^{2} \quad$ : koefisien detecrminasi

$\mathrm{n} \quad$ : jumlah data atau kasus

$\mathrm{k}$ : jumlah variabel independen

c. Kriteria pengujian :

Ho diterima jika $F_{\text {hitung }} \leq F_{\text {tabel }}$ pada $\alpha=5 \%$

Ho ditolak jika $F_{\text {hitung }}>F_{\text {tabel }}$ pada $\alpha=5 \%$

d. Membuat keputusan : Jika Ho diterima atau menolak $\mathrm{Ha}$ : artinya tidak ada pengaruh online marketing strategy yang ditinjau dari variabel product $\left(\mathrm{X}_{1}\right)$, price $\left(\mathrm{X}_{2}\right)$, place $\left(\mathrm{X}_{3}\right)$ dan promotion $\left(\mathrm{X}_{4}\right)$ secara simultan terhadap keputusan pembelian $(\mathrm{Y})$.

Jika Ho ditolak atau menerima $\mathrm{Ha}$ : artinya ada pengaruh online marketing strategy yang ditinjau dari variabel product $\left(\mathrm{X}_{1}\right)$, price $\left(\mathrm{X}_{2}\right)$, place $\left(\mathrm{X}_{3}\right)$ dan promotion $\left(\mathrm{X}_{4}\right)$ secara simultan terhadap keputusan pembelian (Y). 
e. Merumuskan hipotesis yang dapat dirumuskan sebagai berikut:

Ho: $\mathbf{b}_{1}, \mathbf{b}_{2}, \mathbf{b}_{3}, \mathbf{b}_{4}=\mathbf{0} \quad$ :

diduga tidak terdapat pengaruh yang positif dan signifikan online marketing strategy ditinjau dari aspek product $\left(\mathrm{X}_{1}\right)$, price $\left(\mathrm{X}_{2}\right)$, place $\left(\mathrm{X}_{3}\right)$ dan promotion $\left(\mathrm{X}_{4}\right)$ secara parsial terhadap keputusan pembelian $(\mathrm{Y})$.

$\mathbf{H a}: \mathbf{b}_{1}, \mathbf{b}_{\mathbf{2}}, \mathbf{b}_{3}, \mathbf{b}_{\mathbf{4}} \neq \mathbf{0}$ :

diduga terdapat pengaruh yang positif dan signifikan online marketing strategy ditinjau dari aspek product $\left(\mathrm{X}_{1}\right)$, price $\left(\mathrm{X}_{2}\right)$, place $\left(\mathrm{X}_{3}\right)$ dan promotion $\left(\mathrm{X}_{4}\right)$ secara parsial terhadap keputusan pembelian $(\mathrm{Y})$.

f. Melakukan Uji t (secara parsial) Nilai-nilai koefisien regresi dalam persamaan regresi merupakan hasil perhitungan berdasarkan sampel yang terpilih. Dilakukan juga uji t untuk masing-masing nilai koefisien regresi dalam persamaan regresi. Pengujian ini dimaksudkan untuk mengetahui pengaruh variabel bebas terhadap variabel terikat secara parsial. Variabel bebas dikatakan berpengaruh terhadap variabel terikat bisa dilihat dari probabilitas variabel bebas dibandingkan dengan tingkat kesalahan ( $\alpha$ ).

Menurut Sugiyono, (2010: 250) thitung dapat dicari dengan rumus sebagai berikut :

$$
\mathrm{t}=\frac{\mathrm{r} \sqrt{\mathrm{n}-2}}{\sqrt{1-\mathrm{r}^{2}}}
$$

dimana :

$$
\begin{array}{ll}
\mathrm{t} & : \text { thitung } \\
\mathrm{r} & \text { : koefisien korelasi } \\
\mathrm{n} & : \text { jumlah sampel }
\end{array}
$$

g. Kriteria pengujian :
Ho diterima jika tabel $\leq$ thitung $\leq$ tabel Ho ditolak jika thitung $<$ tabel atau thitung $>t_{\text {tabel }}$

h. Membuat keputusan :

Jika Ho diterima atau menolak $\mathrm{Ha}$

artinya tidak ada pengaruh online marketing strategy yang ditinjau dari variabel product $\left(\mathrm{X}_{1}\right)$, price $\left(\mathrm{X}_{2}\right)$, place $\left(\mathrm{X}_{3}\right)$ dan promotion $\left(\mathrm{X}_{4}\right)$ secara parsial terhadap keputusan pembelian $(\mathrm{Y})$.

Jika Ho ditolak atau menerima $\mathrm{Ha}$ : artinya ada pengaruh online marketing strategy yang ditinjau dari variabel product $\left(\mathrm{X}_{1}\right)$, price $\left(\mathrm{X}_{2}\right)$, place $\left(\mathrm{X}_{3}\right)$ dan promotion $\left(\mathrm{X}_{4}\right)$ secara parsial terhadap keputusan pembelian $(\mathrm{Y})$.

i. Menghitung Determinasi $\left(R^{2}\right)$

Digunakan untuk melihat besar pengaruh variabel bebas terhadap variabel terikat. Persamaan dengan model persamaan tersebut akan dapat dihitung $\mathrm{R}^{2}$ (coefficient of determination) yang menunjukkan persentasi dari variasi variabel product $\left(\mathrm{X}_{1}\right)$, price $\left(\mathrm{X}_{2}\right)$, place $\left(\mathrm{X}_{3}\right)$ dan promotion $\left(\mathrm{X}_{4}\right)$ dapat diketahui faktor terpenting atau dominan yang menentukan pengarunya terhadap keputusan pembelian (Y). Jika $R^{2}$ semakin besar (mendekati satu), maka dapat dikatakan bahwa pengaruh variabel bebas yaitu variabel product $\left(\mathrm{X}_{1}\right)$, price $\left(\mathrm{X}_{2}\right)$, place $\left(\mathrm{X}_{3}\right)$ dan promotion $\left(\mathrm{X}_{4}\right)$ terhadap keputusan pembelian $(\mathrm{Y})$

\section{F. HASIL PENELITIAN}

\section{Analisis Data}

Setelah data-data terkumpul maka dilakukan suatu analisis data. 
Analisis data merupakan suatu proses mengolah data dari penyebaran angket yang telah dilakukan. Dari analisis data akan didapat hasil yang nantinya dipakai untuk menguji hipotesis. Dalam penelitian ini data yang diperoleh dianalisis dengan menggunakan teknik statistik, yang dalam pengolahan datanya akan dibantu dengan menggunakan alat bantu yaitu program aplikasi statistik SPSS 20.0 for windows.

Adapun tahapan-tahapan analisis dalam penelitian ini meliputi :

\section{Uji Validitas}

Uji validitas adalah untuk mengetahui kelayakan butir-butir dalam suatu daftar pertanyaan dengan variabel. Uji ini dilakukan untuk mengukur data yang telah di dapat setelah penelitian. Validitas berhubungan dengan ketepatan alat ukur melakukan tugasnya mencapai sasarannya. Data yang diperoleh melalui kuesioner dapat menjawab tujuan penelitian. Untuk memperoleh hasil yang terarah dengan kriteria sebagai berikut :

- Jika $r_{\text {hitung }}>r_{\text {tabel, }}$ maka pertanyaan dinyatakan valid.

- Jika $r_{\text {hitung }} r_{\text {tabel, maka pertanyaan }}$ dinyatakan tidak valid.

Adapun hasil dari uji validitas dalam penelitian ini dapat dilihat pada tabel di bawah ini.

Tabel Hasil Uji Validitas

\begin{tabular}{|c|c|c|c|c|}
\hline No. & Variabel & Nilai Yhitung & Nilai $r_{\text {tabel }}$ & Keterangan \\
\hline 1. & $\begin{array}{l}\text { Product }\left(\mathrm{X}_{1}\right) \\
\text { Pernyataan } 1 \\
\text { Pernyataan } 2 \\
\text { Pernyataan } 3 \\
\text { Pernyataan } 4\end{array}$ & $\begin{array}{l}.727^{\star *} \\
.651^{\star *} \\
.459^{* *} \\
.761^{* *}\end{array}$ & $\begin{array}{l}0,279 \\
0,279 \\
0,279 \\
0,279\end{array}$ & $\begin{array}{l}r_{\text {hitung }}>r_{\text {tabel }}=\text { Valid } \\
r_{\text {hitung }}>r_{\text {tabel }}=\text { Valid } \\
r_{\text {hitung }}>r_{\text {tabel }}=\text { Valid } \\
r_{\text {hitung }}>r_{\text {tabel }}=\text { Valid }\end{array}$ \\
\hline 2. & $\begin{array}{l}\text { Price }\left(\mathrm{X}_{2}\right) \\
\text { Pernyataan } 1 \\
\text { Pernyataan } 2 \\
\text { Pernyataan } 3 \\
\text { Pernyataan } 4\end{array}$ & $\begin{array}{l}.853^{* \star} \\
.381^{* *} \\
.793^{\star *} \\
.854^{* *}\end{array}$ & $\begin{array}{l}0,279 \\
0,279 \\
0,279 \\
0,279\end{array}$ & $\begin{array}{l}r_{\text {hitung }}>r_{\text {tabel }}=\text { Valid } \\
r_{\text {hitung }}>r_{\text {tabel }}=\text { Valid } \\
r_{\text {hitung }}>r_{\text {tabel }}=\text { Valid } \\
r_{\text {hitung }}>r_{\text {tabel }}=\text { Valid }\end{array}$ \\
\hline 3. & $\begin{array}{l}\text { Place }\left(\mathrm{X}_{3}\right) \\
\text { Pernyataan } 1 \\
\text { Pernyataan } 2 \\
\text { Pernyataan } 3 \\
\text { Pernyataan } 4 \\
\end{array}$ & $\begin{array}{l}.754^{* *} \\
.958^{* *} \\
.966^{* *} \\
.966^{* *}\end{array}$ & $\begin{array}{l}0,279 \\
0,279 \\
0,279 \\
0,279 \\
\end{array}$ & $\begin{array}{l}r_{\text {hitung }}>r_{\text {tabel }}=\text { Valid } \\
r_{\text {hitung }}>r_{\text {tabel }}=\text { Valid } \\
r_{\text {hitung }}>r_{\text {tabel }}=\text { Valid } \\
r_{\text {hitung }}>r_{\text {tabel }}=\text { Valid }\end{array}$ \\
\hline 4. & $\begin{array}{l}\text { Promotion }\left(\mathrm{X}_{4}\right) \\
\text { Pernyataan } 1 \\
\text { Pernyataan } 2 \\
\text { Pernyataan } 3 \\
\text { Pernyataan } 4 \\
\end{array}$ & $\begin{array}{l}.776^{\star \star} \\
.715^{* \star} \\
.453^{* \star} \\
.776^{* \star}\end{array}$ & $\begin{array}{l}0,279 \\
0,279 \\
0,279 \\
0,279\end{array}$ & $\begin{array}{l}r_{\text {hitung }}>r_{\text {tabel }}=\text { Valid } \\
r_{\text {hitung }}>r_{\text {tabel }}=\text { Valid } \\
r_{\text {hitung }}>r_{\text {tabel }}=\text { Valid } \\
r_{\text {hitung }}>r_{\text {tabel }}=\text { Valid }\end{array}$ \\
\hline 5. & $\begin{array}{l}\text { Keputusan Pembelian }(\mathrm{Y}) \\
\text { Pernyataan } 1 \\
\text { Pernyataan } 2 \\
\text { Pernyataan } 3 \\
\text { Pernyataan } 4 \\
\text { Pernyataan } 5\end{array}$ & $\begin{array}{l}.680^{* *} \\
.753^{\star *} \\
.538^{* *} \\
.659^{\star *} \\
.713^{\star *}\end{array}$ & $\begin{array}{l}0,279 \\
0,279 \\
0,279 \\
0,279 \\
0,279 \\
\end{array}$ & $\begin{array}{l}r_{\text {hitung }}>r_{\text {tabel }}=\text { Valid } \\
r_{\text {hitung }}>r_{\text {tabel }}=\text { Valid } \\
r_{\text {hitung }}>r_{\text {tabel }}=\text { Valid } \\
r_{\text {hitung }}>r_{\text {tabel }}=\text { Valid } \\
r_{\text {hitung }}>r_{\text {tabel }}=\text { Valid }\end{array}$ \\
\hline
\end{tabular}

Sumber : data primer (hasil jawaban responden, diolah kembali, 2019

Dari tabel di atas dapat diketahui perbandingan antara nilai $r_{\text {hitung }}$ dan $r_{\text {tabel }}$ dari masing-masing item pertanyaan. $r_{\text {tabel }}$ dicari pada signifikansi 0,05 dengan uji 2 sisi dan jumlah data $(\mathrm{N})=50$, maka didapat

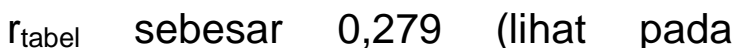
lampiran Tabel $r$ ProductMoment). Karena semua item pertanyaan pada masing-masing variabel nilai $r_{\text {hitungnya }}$ lebih besar dari $r_{\text {tabel }}$ yaitu 0,279 sehingga dapat dikatakan bahwa 
semua pertanyaan instrumen adalah valid.

\section{Uji Reliabilitas}

Uji reliabilitas digunakan untuk menunjukan konsistensi dari jawaban responden terhadap pertanyaan yang terdapat pada kuesioner dimana telah diuji validitasnya. Suatu instrumen yang dipakai dalam variabel dikatakan handal (reliabel) bila memiliki koefisien Cronbach's Alpha lebih dari 0,60 (Priyanto, 2010:98).

Hasil uji reliabilitas pada penelitian ini dapat dilihat pada tabel di bawah ini :

Tabel Hasil Uji Reliabilitas

\begin{tabular}{|c|l|c|c|}
\hline No. & \multicolumn{1}{|c|}{ Variabel } & Cronbach Alpha & Keterangan \\
\hline 1. & Product $\left(\mathrm{X}_{1}\right)$ & .621 & Reliabel \\
\hline 2. & Price $\left(\mathrm{X}_{2}\right)$ & .689 & Reliabel \\
\hline 3. & Place $\left(\mathrm{X}_{3}\right)$ & .927 & Reliabel \\
\hline 4. & Promotion $\left(\mathrm{X}_{4}\right)$ & .639 & Reliabel \\
\hline 5. & Keputusan Pembelian $(\mathrm{Y})$ & .685 & Reliabel \\
\hline
\end{tabular}

Sumber : data primer (hasil jawaban responden, diolah kembali, 2019

Dari tabel di atas hasil uji reliabilitas dapat diketahui bahwa variabel Keputusan Pembelian (Y) Product $\left(\mathrm{X}_{1}\right)$, Price $\left(\mathrm{X}_{2}\right)$, Place $\left(\mathrm{X}_{3}\right)$, dan Promotion $\left(\mathrm{X}_{4}\right)$ memiliki nilai lebih besar dari 0,60. Dari masing-masing variabel tersebut dikatakan handal (reliable) untuk digunakan sebagai alat ukur, karena nilai Cronbach Alpha lebih besar dari 0,60.

\section{Analisis Regresi Linier Berganda}

Analisis regresi linier berganda digunakan dalam penelitian ini dengan tujuan untuk membuktikan hipotesis mengenai pengaruh Product $\left(\mathrm{X}_{1}\right)$,
Price $\left(\mathrm{X}_{2}\right)$, Place $\left(\mathrm{X}_{3}\right)$, dan Promotion $\left(X_{4}\right)$ secara parsial maupun secara bersama-sama terhadap Keputusan Pembelian (Y).

Perhitungan statistik dalam analisis regresi linier berganda yang digunakan dalam penelitian ini adalah dengan menggunakan alat bantu yaitu program aplikasi statistik SPSS 20.0 for windows. Hasil pengolahan data dengan menggunakan alat bantu program aplikasi statistik SPSS 20.0 for windows selengkapnya ada pada lampiran dan selanjutnya dijeskan pada tabel berikut ini :

\section{TabelHasil Pengujian Regresi Linier Berganda}

\section{Coefficients $^{a}$}

\begin{tabular}{|c|c|c|c|c|c|c|}
\hline \multirow{2}{*}{\multicolumn{2}{|c|}{ Model }} & \multicolumn{2}{|c|}{ Unstandardized Coefficients } & \multirow{2}{*}{$\begin{array}{c}\text { Standardized } \\
\text { Coefficients }\end{array}$} & \multirow[b]{2}{*}{$\mathrm{t}$} & \multirow[b]{2}{*}{ Sig. } \\
\hline & & $\mathrm{B}$ & Std. Error & & & \\
\hline \multirow[t]{5}{*}{1} & (Constant) & 7.435 & 2.090 & & 3.558 & .001 \\
\hline & Product & .307 & .097 & .289 & 3.165 & .002 \\
\hline & Price & .743 & .111 & .729 & 6.682 & .000 \\
\hline & Place & .011 & .073 & .013 & .153 & .879 \\
\hline & Promotion & .273 & .124 & .207 & 2.209 & .031 \\
\hline
\end{tabular}

a. Dependent Variable: Keputusan Pembelian

Sumber : data primer (hasil jawaban responden, diolah kembali, 2019

Dari tabel di atas bentuk unstandardized coefficients beta maka diperoleh persamaan regresi sebagai berikut : 
$Y=a+b_{1} X_{1}+b_{2} X_{2}+b_{3} X_{3}+b_{4} X_{4}$

$Y=7,435+0,307 X_{1}+0,743 X_{2}+$ $0,011 X_{3}+0,273 X_{4}$

Keterangan :

$\mathrm{Y} \quad=$ Keputusan Pembelian

a $=$ Konstanta

$\mathrm{b}_{1-4}=$ Koefisien Regresi

$\mathrm{X}_{1}=$ Product

$\mathrm{X}_{2}=$ Price

$\mathrm{X}_{3}=$ Place

$\mathrm{X}_{4}=$ Promotion

Persamaan regresi linier berganda di atas dapat dijelaskan sebagai berikut :

a. Konstanta sebesar 7,435; artinya jika Product $\left(\mathrm{X}_{1}\right), \quad \operatorname{Price}\left(\mathrm{X}_{2}\right)$, Place $\left(\mathrm{X}_{3}\right)$, dan Promotion $\left(\mathrm{X}_{4}\right)$ nilainya adalah 0 , maka Keputusan Pembelian (Y) nilainya 7,435 .

b. Koefisien regresi variabel Product $\left(\mathrm{X}_{1}\right)$ dengan nilai 0,307 ; artinya jika Productmengalami kenaikan 1\%, maka Keputusan Pembelian ( $Y$ ) akan mengalami penurunan sebesar 0,307 dengan asumsi variabel independen lain nilainya tetap. Koefisien bernilai positif artinya terjadi hubungan positif antara Productdengan Keputusan Pembelian, semakin naik Product, maka semakin meningkat Keputusan Pembelian.

c. Koefisien regresi variabel $\operatorname{Price}\left(\mathrm{X}_{2}\right)$ dengan nilai 0,743 ; artinya jika Pricemengalami kenaikan 1\%, maka Keputusan Pembelian (Y) akan mengalami peningkatan sebesar 0,743 dengan asumsi variabel independen lain nilainya tetap. Koefisien bernilai positif artinya terjadi hubungan positif antara Pricedengan Keputusan Pembelian, semakin naik Price, maka semakin meningkat Keputusan Pembelian.

d. Koefisien regresi variabel Place $\left(\mathrm{X}_{3}\right)$ dengan nilai 0,011 ; artinya jika Placemengalami kenaikan 1\%, maka Keputusan Pembelian (Y) akan mengalami peningkatan sebesar 0,011 dengan asumsi variabel independen lain nilainya tetap. Koefisien bernilai positif artinya terjadi hubungan positif antara Placedengan Keputusan Pembelian, semakin naik Place, maka semakin meningkat Keputusan Pembelian.

e. Koefisien regresi variabel Promotion $\left(\mathrm{X}_{4}\right)$ dengan nilai 0,273; artinya jika Promotionmengalami kenaikan $1 \%$, maka Keputusan Pembelian (Y) akan mengalami peningkatan sebesar 0,273 dengan asumsi variabel independen lain nilainya tetap. Koefisien bernilai positif artinya terjadi hubungan positif antara Promotiondengan Keputusan Pembelian, semakin naik Promotion, maka semakin meningkat Keputusan Pembelian.

\section{Analisis Pengujian Secara Simultan (Uji F) \\ Uji $F$ dilakukan untuk melihat} secara bersama-sama apakah ada pengaruh positif dan signifikan dari variabel bebas $(X)$ terhadap variabel terikat $(Y)$. Metode yang digunakan uji $F$ terhadap signifikan model regresi yang menunjukkan mampu tidaknya model atau persamaan yang terbentuk dalam memprediksi nilai variabel terikat dengan tepat.

Adapun hasil dari uji $F$ pada penelitian ini dapat dilihat pada tabel di bawah ini: 
Tabel Hasil Uji Simultan (Uji F)

ANOVA $^{\text {b }}$

\begin{tabular}{|ll|r|r|r|r|r|}
\hline Model & & Sum of Squares & Df & Mean Square & F & Sig. \\
\hline 1 & Regression & 401.907 & 4 & 100.477 & 22.133 & $.000^{\mathrm{a}}$ \\
& Residual & 295.078 & 65 & 4.540 & & \\
& Total & 696.986 & 69 & & & \\
\hline
\end{tabular}

a. Predictors: (Constant), Promotion, Place, Product, Price

b. Dependent Variable: Keputusan Pembelian

Sumber : data primer (hasil jawaban responden, diolah kembali, 2019

Kriteria uji yang digunakan adalah :

Ho diterima dan Ha ditolak jika $F_{\text {hitung }}<F_{\text {tabel }}$

Ha diterima dan Ho ditolak jika $F_{\text {hitung }}>F_{\text {tabel }}$

Berdasarkan hasil uji $\mathrm{F}$ pada tabel diperoleh $F_{\text {hitung }}$ sebesar 22,133 dengan tingkat nilai signifikansi sebesar 0,000 dengan tingkat kesalahan 0,05 dengan df 1 (jumlah variabel 1 ) atau 5-1 = 4, dan df $2(n-k-$ 1) atau $50-4-1=45$ (n adalah jumlah kasus dan $\mathrm{k}$ adalah jumlah variabel independen), hasil yang diperoleh untuk $F_{\text {tabel }}$ sebesar 2,422.Jadi dapat kesimpulannya $F_{\text {hitung }}>F_{\text {tabel }}(22,133>$ $2,422)$ dan tingkat signifikan $(0,000<$ $0,05)$, maka hipotesis nol ditolak, sehingga disimpulkan bahwa variabel Product $\left(\mathrm{X}_{1}\right)$, Price $\left(\mathrm{X}_{2}\right)$, Place $\left(\mathrm{X}_{3}\right)$, dan Promotion $\left(\mathrm{X}_{4}\right)$ secara bersamasama berpengaruh terhadap Keputusan Pembelian (Y).

\section{Analisis Pengujian Secara Parsial (Uji t)}

Uji ini digunakan untuk mengetahui apakah dalam model regresi variabel bebas variabel Product $\left(\mathrm{X}_{1}\right)$, Price $\left(\mathrm{X}_{2}\right)$, Place $\left(\mathrm{X}_{3}\right)$, dan Promotion $\left(\mathrm{X}_{4}\right)$ secara parsial mempunyai pengaruh yang signifikan terhadap variabel terikat Keputusan Pembelian (Y).

Adapun hasil dari uji t pada penelitian ini dapat dilihat pada tabel di bawah ini:

Tabel Hasil Uji Parsial (Uji t)

Coefficients $^{\mathrm{a}}$

\begin{tabular}{|c|c|c|c|c|c|c|}
\hline \multirow{2}{*}{\multicolumn{2}{|c|}{ Model }} & \multicolumn{2}{|c|}{ Unstandardized Coefficients } & \multirow{2}{*}{$\begin{array}{c}\begin{array}{c}\text { Standardized } \\
\text { Coefficients }\end{array} \\
\text { Beta }\end{array}$} & \multirow[b]{2}{*}{$\mathrm{T}$} & \multirow[b]{2}{*}{ Sig. } \\
\hline & & B & Std. Error & & & \\
\hline \multirow[t]{5}{*}{1} & (Constant) & 7.435 & 2.090 & & 3.558 & .001 \\
\hline & Product & .307 & .097 & .289 & 3.165 & .002 \\
\hline & Price & .743 & .111 & .729 & 6.682 & .000 \\
\hline & Place & .011 & .073 & .013 & .153 & .879 \\
\hline & Promotion & .273 & .124 & .207 & 2.209 & .031 \\
\hline
\end{tabular}

a. Dependent Variable: Keputusan Pembelian

Sumber : data primer (hasil jawaban responden, diolah kembali, 2019

Kriteria pengambilan keputusan :

Ho diterima dan Ha ditolak jika $t_{\text {hitung }}<t_{\text {tabel }}$ $\mathrm{Ha}$ diterima dan Ho ditolak jika $t_{\text {hitung }}>t_{\text {tabel }}$
Berdasarkan tabel di atas hasil uji parsial (Uji t) di atas dapat dijelaskan bahwa : 
a. Variabel Product $\left(\mathrm{X}_{1}\right)$

Hasil pengujian diperoleh thitung sebesar 3,165 dengan nilai signifikan sebesar 0,002 dan tabel yang dapat dilihat pada tabel statistik pada signifikan 0,05, dengan derajat kebebasan df 2 (n-k-1) atau 50-4-1 = 45, hasil diperoleh untuk $t_{\text {tabel }}$ sebesar 1,679 , jadi nilai thitung $>t_{\text {tabel }}(3,165$ $>1,679$ ), jadi hipotesis alternatif diterima dan hipotesis nol ditolak, bahwa Product $\left(\mathrm{X}_{1}\right)$ berpengaruh signifikan terhadap Keputusan Pembelian ( $\mathrm{Y}$ ).

b. Variabel Price $\left(\mathrm{X}_{2}\right)$

Hasil pengujian diperoleh thitung sebesar 6,682 dengan nilai signifikan sebesar 0,000 dan tabel yang dapat dilihat pada tabel statistik pada signifikan 0,05, dengan derajat kebebasan df 2 (n-k-1) atau 50-4-1 = 45, hasil diperoleh untuk tabel sebesar 1,679 , jadi nilai $t_{\text {hitung }}>t_{\text {tabel }}(6,682$ $>1,679)$, jadi hipotesis alternatif diterima dan hipotesis nol ditolak, bahwa Price $\left(\mathrm{X}_{2}\right)$ berpengaruh signifikan terhadap Keputusan Pembelian (Y).

c. Variabel Place $\left(\mathrm{X}_{3}\right)$

Hasil pengujian diperoleh thitung sebesar 0,153 dengan nilai signifikan sebesar 0,307 dan tabel yang dapat dilihat pada tabel statistik pada signifikan 0,05, dengan derajat kebebasan df 2 $(n-k-1)$ atau 50-4-1 = 45, hasil diperoleh untuk tabel sebesar 1,679 , jadi nilai $t_{\text {hitung }}<t_{\text {tabel }}(0,153$ $<1,679$ ), jadi hipotesis alternatif ditolak dan hipotesis nol diterima, bahwa Place $\left(\mathrm{X}_{3}\right)$ tidak berpengaruh signifikan terhadap Keputusan Pembelian (Y).

d. Variabel Promotion $\left(\mathrm{X}_{4}\right)$ Hasil pengujian diperoleh thitung sebesar 2,209 dengan nilai signifikan sebesar 0,031 dan tabel yang dapat dilihat pada tabel statistik pada signifikan 0,05, dengan derajat kebebasan df 2 (n-k-1) atau 50-4-1 = 45, hasil diperoleh untuk tabel sebesar 1,679 , jadi nilai thitung $>t_{\text {tabel }}(2,209$ $>1,679$ ), jadi hipotesis alternatif diterima dan hipotesis nol ditolak, bahwa Promotion ( $\left.\mathrm{X}_{4}\right)$ berpengaruh tapi tidak signifikan terhadap Keputusan Pembelian (Y).

\section{Analisis Koefisien Determinasi $\left(R^{2}\right)$}

Analisis koefisien determinasi ini digunakan untuk mengetahui seberapa besar pengaruh variabel-variabel bebas memiliki pengaruh terhadap variabel terikat. Nilai koefesien determinasi untuk variabel bebas lebih dari dua digunakan Adjusted $R$ Square sebagai berikut :

Tabel Koefisien Determinasi $\left(\mathbf{R}^{2}\right)$ Model Summary

\begin{tabular}{l|r|r|r|r|}
\hline Model & $\mathrm{R}$ & $\mathrm{R}$ Square & Adjusted R Square & $\begin{array}{c}\text { Std. Error of the } \\
\text { Estimate }\end{array}$ \\
\hline 1 & $.759^{\mathrm{a}}$ & .577 & .551 & 2.131 \\
\hline
\end{tabular}
a. Predictors: (Constant), Promotion, Place, Product, Price
Sumber : data primer (hasil jawaban responden, diolah kembali, 2019

Dari tabel di atas uji nilai koefisien determinasi bertujuan untuk menunjukkan persentase tingkat kebenaran prediksi dari penguji regresi yang dilakukan, semakin besar Adjusted $R$ square maka semakin 
besar variasi dari variabel dapat dijelaskan oleh variabel bebas. Koefisien determinasi Adjusted $R$ Square yang diperoleh adalah 0,551 $(55,1 \%)$ berarti bahwa variabel Product $\left(\mathrm{X}_{1}\right)$, Price $\left(\mathrm{X}_{2}\right)$, Place $\left(\mathrm{X}_{3}\right)$, dan Promotion $\left(\mathrm{X}_{4}\right)$ menjelaskan Keputusan Pembelian (Y) sebesar $55,1 \%$ sedangkan sisanya $44,9 \%$ (100\% - 55,1\%) dapat dijelaskan oleh variabel lain yang tidak diteliti dalam penelitian ini.

\section{G. PEMBAHASAN}

Berdasarkan analisa hasil penelitian yang telah dilakukan untuk mengetahui pengaruh strategi pemasaran online yang ditinjau dari variabel product, price, place dan promotion terhadap keputusan pembelian pada mahasiswa STIE Mulia Darma Pratama Palembangdapat ditarik kesimpulan sebagai berikut :

a. Berdasarkan hasil pengujian secara simultan (Uji $F)$, hasil yang diperoleh untuk $F_{\text {hitung }}>F_{\text {tabel }}(22,133>2,422)$ dan tingkat signifikan $0,000<0,05$, maka hipotesis nol ditolak, sehingga disimpulkan bahwa variabel Product $\left(X_{1}\right)$, Price $\left(X_{2}\right)$, Place $\left(X_{3}\right)$, dan Promotion $\left(\mathrm{X}_{4}\right)$ secara bersamasama berpengaruh terhadap Keputusan Pembelian (Y).

b. Berdasarkan hasil pengujian secara parsial (Uji t) dapat dijelaskan :

1) Variabel Product $\left(X_{1}\right)$ berpengaruh signifikan terhadap Keputusan Pembelian $(Y)$ hasil diperoleh thitung sebesar 3,165 dengan nilai signifikan $0,002<$ 0,05 , jadi nilai $t_{\text {hitung }}>t_{\text {tabel }}(3,165>$ $1,679)$ hipotesis alternatif diterima dan hipotesis nol ditolak.

2) Variabel Price $\left(X_{2}\right)$ berpengaruh signifikan terhadap Keputusan Pembelian ( $\mathrm{Y})$ hasil diperoleh thitung sebesar 6,682 dengan nilai signifikan $0,000<0,05$, jadi nilai $t_{\text {hitung }}>t_{\text {tabel }}(6,682>1,679)$ hipotesis alternatif diterima dan hipotesis nol ditolak.

3) Variabel Place $\left(X_{3}\right)$ tidak berpengaruh signifikan terhadap Keputusan Pembelian (Y) hasil diperoleh $t_{\text {hitung }}$ sebesar 0,153 dengan nilai signifikan $0,879>$ 0,05 , jadi nilai $t_{\text {hitung }}<t_{\text {tabel }}(0,153<$ $1,679)$ hipotesis alternatif ditolak dan hipotesis nol diterima.

4) Variabel Promotion

berpengaruh tapi tidak signifikan terhadap Keputusan Pembelian $(Y)$ hasil diperoleh thitung sebesar 2,209 dengan nilai signifikan sebesar 0,031>0,05, jadi nilai $t_{\text {hitung }}>t_{\text {tabel }}(2,209>1,679)$ hipotesis alternatif diterima dan hipotesis nol ditolak.

c. Berdasarkan hasil Koefisien determinasi $R^{2}$ yang diperoleh adalah 0,577 (57,7\%) berarti bahwa variabel Product $\left(\mathrm{X}_{1}\right)$, Price $\left(\mathrm{X}_{2}\right)$, Place $\left(\mathrm{X}_{3}\right)$, dan Promotion $\left(\mathrm{X}_{4}\right)$ menjelaskan Keputusan Pembelian (Y) sebesar $55,1 \%$ sedangkan sisanya $44,9 \% \quad(100 \%-55,1 \%)$ dapat dijelaskan oleh variabel lain yang tidak diteliti dalam penelitian ini.

\section{H. KESIMPULAN DAN SARAN}

1. Kesimpulan

Berdasarkan analisa hasil penelitian yang telah dilakukan untuk mengetahui pengaruh online marketing strategy yang ditinjau dari variabel product, price, place dan promotion terhadap keputusan pembeliandapat ditarik kesimpulan sebagai berikut :

a. Hasil pengujian secara simultan (Uji $F)$, hasil yang diperoleh untuk $F_{\text {hitung }}>F_{\text {tabel }}(22,133>2,422)$ dan tingkat signifikan $0,000<0,05$, maka hipotesis nol ditolak, sehingga disimpulkan bahwa variabel Product $\left(\mathrm{X}_{1}\right)$, Price $\left(\mathrm{X}_{2}\right)$, Place $\left(\mathrm{X}_{3}\right)$, dan Promotion $\left(\mathrm{X}_{4}\right)$ secara bersama- 
sama berpengaruh terhadap Keputusan Pembelian (Y).

b. Hasil pengujian secara parsial (Uji t) dapat dijelaskan :

1) Variabel Product $\left(X_{1}\right)$ berpengaruh signifikan terhadap Keputusan Pembelian (Y) hasil diperoleh thitung sebesar 3,165 dengan nilai signifikan $0,002<$ 0,05 , jadi nilai $t_{\text {hitung }}>t_{\text {tabel }}(3,165>$ $1,679)$ hipotesis alternatif diterima dan hipotesis nol ditolak.

2) Variabel Price $\left(X_{2}\right)$ berpengaruh signifikan terhadap Keputusan Pembelian (Y) hasil diperoleh thitung sebesar 6,682 dengan nilai signifikan $0,000<0,05$, jadi nilai thitung $>t_{\text {tabel }}(6,682>1,679)$ hipotesis alternatif diterima dan hipotesis nol ditolak.

3) Variabel Place $\left(X_{3}\right)$ tidak berpengaruh signifikan terhadap Keputusan Pembelian (Y) hasil diperoleh thitung sebesar 0,153 dengan nilai signifikan $0,879>$ 0,05 , jadi nilai $t_{\text {hitung }}<t_{\text {tabel }}(0,153<$ 1,679 ) hipotesis alternatif ditolak dan hipotesis nol diterima.

4) Variabel Promotion $\left(X_{4}\right)$ berpengaruh tapi tidak signifikan terhadap Keputusan Pembelian (Y) hasil diperoleh thitung sebesar 2,209 dengan nilai signifikan sebesar 0,031>0,05, jadi nilai $t_{\text {hitung }}>t_{\text {tabel }}(2,209>1,679)$ hipotesis alternatif diterima dan hipotesis nol ditolak.

c. Hasil Koefisien determinasi $R^{2}$ yang diperoleh adalah $0,577 \quad(57,7 \%)$ berarti bahwa variabel Product $\left(\mathrm{X}_{1}\right)$, Price $\left(\mathrm{X}_{2}\right)$, Place $\left(\mathrm{X}_{3}\right)$, dan Promotion $\left(\mathrm{X}_{4}\right)$ menjelaskan Keputusan Pembelian (Y) sebesar $55,1 \%$ sedangkan sisanya $44,9 \%$ $(100 \%-55,1 \%)$ dapat dijelaskan oleh variabel lain yang tidak diteliti dalam penelitian ini.

\section{Saran}

Berdasarkan kesimpulan yang diperoleh dalam penelitian ini, maka diajukan saran-saran sebagai pelengkap terhadap hasil penelitian yang dapat diberikan sebagai berikut:

a. Disarankan para bisnis online diharapkan dalam memasarkan sebuah produkharus senantiasa memperhatikan unsur promosi penjualanonline, harga, kepercayaan dan kemudahan, jangan hanya menyampaikan segala kelebihannya tanpa menjelaskan kekurangan atau kelemahan dari produk tersebut.

b. Bagi peneliti selanjutnya diharapkan agar dilakukan penelitian lebih lanjut dan lebih mendalam dengan mengembangkan variabel-variabel lain yang belum dapat dijelaskan dalam penelitian ini.

\section{DAFTAR PUSTAKA}

Alma, Buchari. 2013. Manajemen Pemasaran dan Pemasaran Jasa, Cetakan Kesepuluh. Bandung: Penerbit Alfabeta.

Kotler, Philip dan Keller Kevin Lane. 2008. Manajemen Pemasaran. Edisi Ketiga Belas, Jilid Dua. Jakarta: Erlangga.

Kotler, Philip dan Kevin Lane Keller. 2009. Manajemen Pemasaran

1. Edisi ketigabelas. Jakarta: Erlangga.

Kotler, Philip. 2002. Manajemen Pemasaran, Jilid 1, Edisi Milenium. Jakarta: Prehalindo.

Kotler, Philip. 2004. Definisi Strategi Pemasaran. www.sarjanaku.com. 15 Desember 2013 
M. Suyanto. 2007. Strategi Periklanan Pada E-Commerce. Yogyakarta: Andi.

Priyatno, Duwi. 2010. Paham Analisis Statistik Data dengan SPSS Plus! Tata Cara dan Tips Menyusun Skripsi dalam Waktu Singkat!. Yogyakarta: MedKom.
Sugiyono. 2010. Statistik untuk Penelitian. Bandung: Penerbit Alfabeta.

Sunyoto, Danang. 2014.Dasar-Dasar Manajemen Pemasaran, Cetakan Pertama.Yogyakarta: PenerbitCAPS.

Tjiptono, Fandy. 2008. Strategi Pemasaran, Yogyakarta: ANDI. 